\title{
Jurassic palynology from a borehole in the Champagne area, France-correlation of the lower Callovian-middle Oxfordian using sequence stratigraphy
}

\author{
Danielle Fauconnier \\ BRGM, PB 6009, 45060 Orléans-la-Source, France
}

Received 28 December 1992; revised and accepted 29 April 1994

\begin{abstract}
The cored borehole A901, drilled by the National Agency for the Management of Radioactive Waste at Montcornet, in Champagne, on the northeastern border of the Paris Basin, provided a continuous section from the Hettangian to the lower Kimmeridgian. Samples taken at regular intervals yielded marker dinoflagellate cysts of the northwest European domain that have been correlated with ammonite zones.

The earliest dinoflagellate species appear in the upper Sinemurian (976 m, Obtusum zone), whereas the lowest intersected beds contain abundant conifer pollen and pteridophyte spores. The microplankton becomes diversified along the hole, in particular in the Callovian-Oxfordian beds; the Bathonian gravelly oolitic limestones are unfavourable for preservation of microflora.

The sequence-stratigraphical interpretation was based on lithological, sedimentological and biostratigraphical information and seismic profiles. A semi-quantitative estimation of the microplankton content and of the number of species per sample enabled identification of the main transgressive-regressive cycles and condensed sequences in the lower Callovian to middle Oxfordian.
\end{abstract}

\section{Introduction}

Borehole A901 was drilled in 1990 by the Agence Nationale pour la Gestion des Déchets Radioactifs (ANDRA-National Agency for the Management of Radioactive Waste) in the framework of a project for the storage of radioactive waste in the Aisne Department, on the northeastern border of the Paris Basin (Fig. 1). The hole was fully cored, and traversed a succession from Cretaceous (Senonian) to Jurassic (Hettangian) overlying the Lower Devonian basement at $1123 \mathrm{~m}$.

The present investigation only concerns the Jurassic from the Hettangian to the Kimmeridgian; it was carried out to obtain biostratigraphical information on the main trans- gressive-regressive cycles. The objective of this study was to establish a biostratigraphical scale for the Hettangian to the lower Kimmeridgian on the basis of dinoflagellate cysts, concentrating on the markers that have been correlated with ammonite zones. The borehole contains ammonites, however mostly confined to the Lias; for Dogger and Malm, the ammonite biozonation of the UK was used. A semi-quantitative count of dinoflagellate cysts was made in order to follow the evolution of the microplankton. Their evolution has also been correlated with lower Callovian-middle Oxfordian eustatic sea-level variations, paying particular attention to transgressional maxima (Vail et al., 1987; Haq et al., 1988) interpreted from other biostratigraphical, 


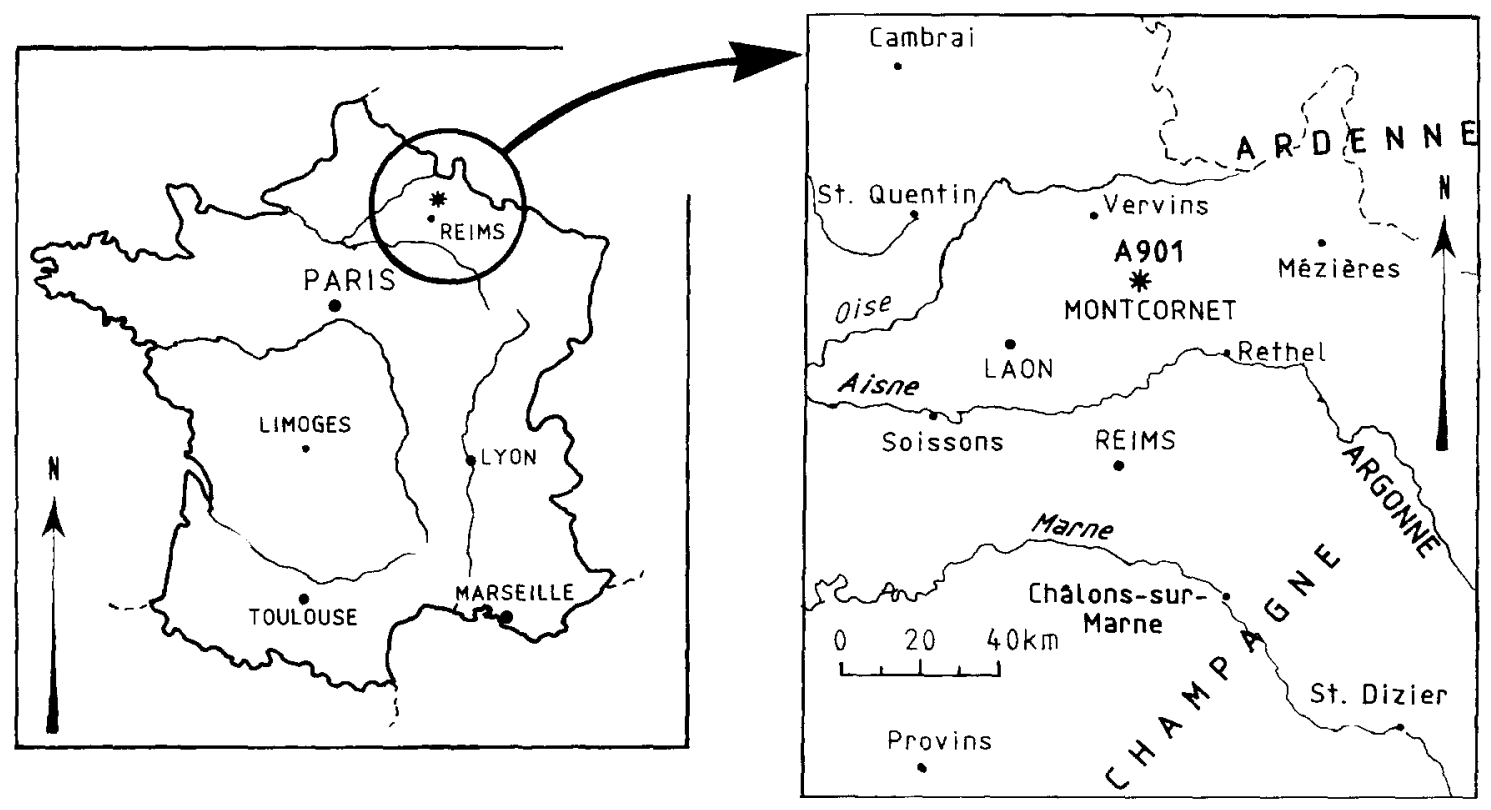

Fig. 1. Location of borehole A901.

sedimentological and lithological data and seismic profiles (Le Strat et al., 1991).

\section{Material and methods}

\subsection{Borehole log}

The Jurassic section (Fig. 2) studied here consists essentially, from base to top, of:

1075.31-865.46 m: Alternating bioturbiditic marl, bioclastic limestone and marl with calcareous clay and limestone.

865.46-692.71 m: Bioclastic silty clay, sandy silt and sandstone.

692.71-478.33 m: Ferruginous or gravelly oolitic limestone with intervals of shelly marl.

478.33-378.72 m: Alternating silty calcareous clay and silty marl.

378.72-319.25 m: Calcareous, sandy-silty mudstone with bioclastic limestone, passing upward to grey calcareous marl with crinoidal limestone.

319.25-261.35 m: Reefal limestone, clayey in places, interbedded with clayey bioclastic limestone.
261.35-204.95 m: Interbedded silty mudstone and sandy limestone, passing upward to calcareous marl and dolomite silt.

\subsection{Sampling}

The study was based on 154 samples taken at intervals of 3 to $5 \mathrm{~m}$, depending to rock type, throughout the length of the borehole.

\subsection{Palynological preparation}

All samples were processed for palynological examination, using standard techniques; $15 \mathrm{~g}$ of material were crushed and treated with hydrochloric $(\mathrm{HCl})$ and hydrofluoric acids (HF) in order to remove mineral sediment. The residue was sieved using nylon filter with a mesh between 120 and $20 \mu \mathrm{m}$; after oxidation with nitric acid $\left(\mathrm{HNO}_{3}\right)$ for a few minutes, heavy liquid separation was necessary to eliminate the remaining mineral matter. The final residue was washed with distilled water and alcohol.

Two slides were prepared for each sample. 


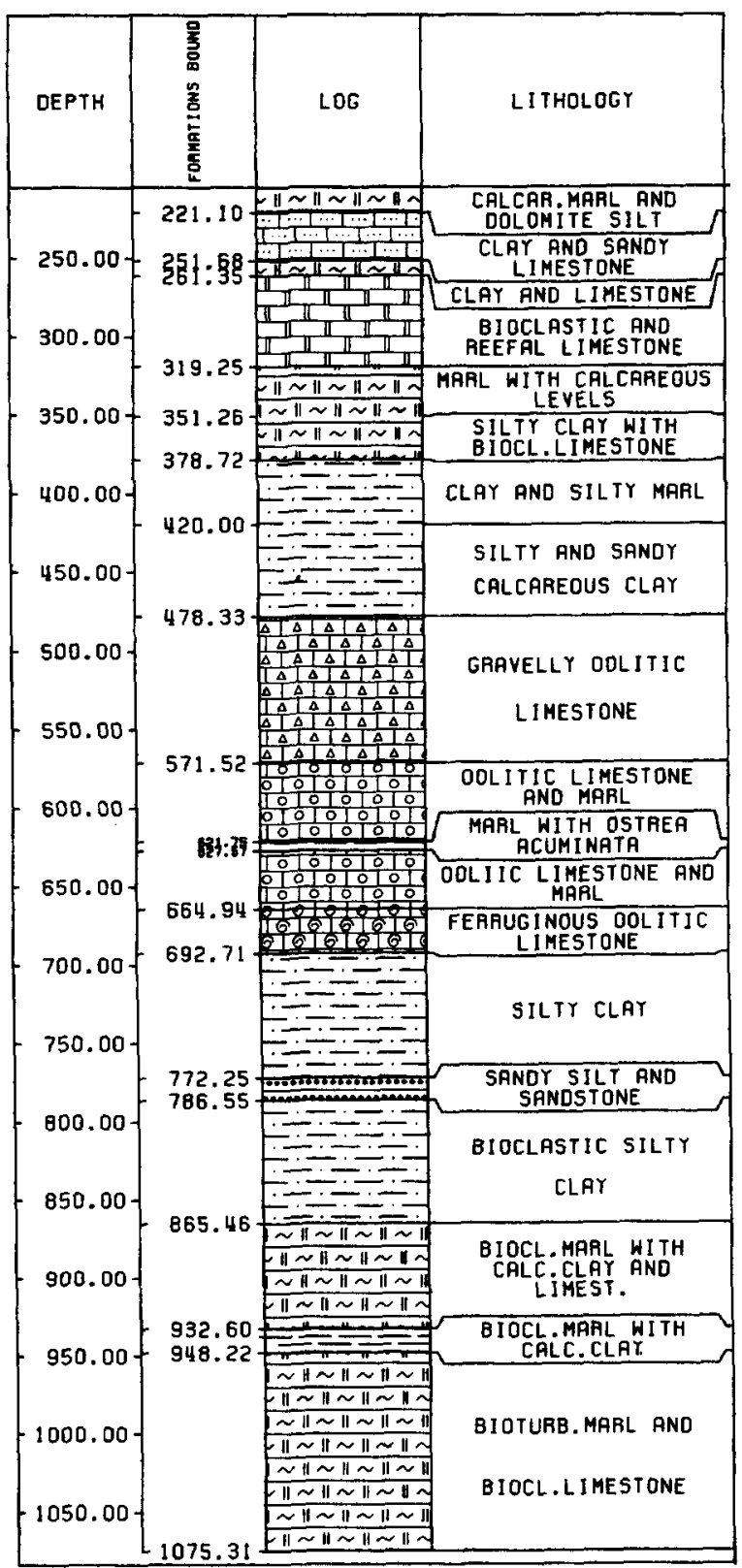

Fig. 2. Schematic stratigraphic log of borehole A901.

\section{Jurassic palynology in northwestern Europe}

A large number of publications on Jurassic dinoflagellate cysts of the northwest European domain have been published during the last thirty years, in Germany (Fenton, 1981; Prauss, 1989; Feist-Burkhardt, 1990), Bulgaria (Dodekova, 1975), Scandinavia (Dybkjaer, 1988), Svalbard (Bjaerke, 1980; Smelror and Aarhus, 1989), and, in particular, in Great Britain (Riding, 1984a-c, 1987). In France, there has been a concentration on the Kimmeridgian (Raynaud, 1978; Ioannides et al., 1988), Lias (de Vains, 1988) and Dogger (Smelror and Leereveld, 1989); however, so far nothing has been published on the Paris Basin.

In contrast, in the North Tethyan domain, there are only reports from Portugal (Davies, 1985), Israel (Conway, 1990) and Lybia (Thusu et al., 1988), making any comparison between boreal and tethyan zonations difficult.

A recent review by Riding and Thomas (1992) covers all studies made on sections of the English Jurassic (Hettangian-Portlandian). They give the distribution of dinoflagellate cysts in relation to ammonite zones of the boreal domain, and present a biozonation based on the appearance and disappearance of marker dinoflagellate cysts.

\section{Palynology of the Champagne borehole}

The great majority of samples studied in Champagne are fossiliferous; the barren intervals are mostly confined to Bathonian oolitic limestones. The microflora in the palynological preparations consists of gymnosperm pollen (Classopollis, disaccate), pteridophyte spores and dinoflagellate cysts. The diversity of the latter increases from the upper Sinemurian onward. The associated organic material consists of ligneous and cuticular debris of continental origin, and algal and marine type sapropelic material. The distribution of selected cysts is shown in Fig. 3. Most of the markers of the zonation of Riding and Thomas (1992) are present. The ammonites found in borehole A901 are shown in Fig. 3, and are mostly confined to the Lias.

The various stages intersected in the borehole are described and commented upon below; Fig. $4 \mathrm{a}-\mathrm{c}$ shows the appearance and disappearance of marker dinoflagellate cysts together with the ammonite zonation for the boreal domain. 


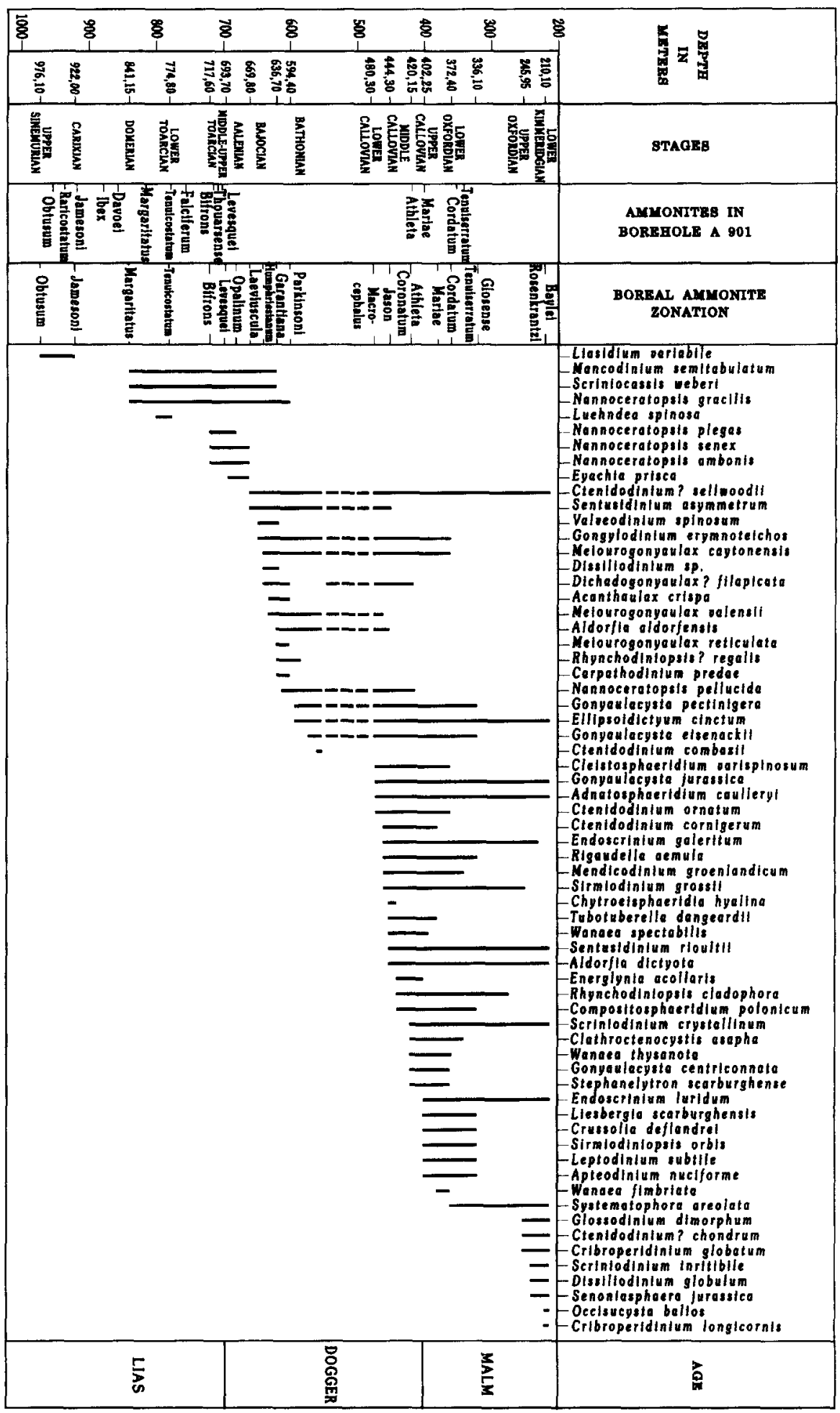

Fig. 3. Stratigraphic distribution of selected dinoflagellate cyst species in borehole A901. 


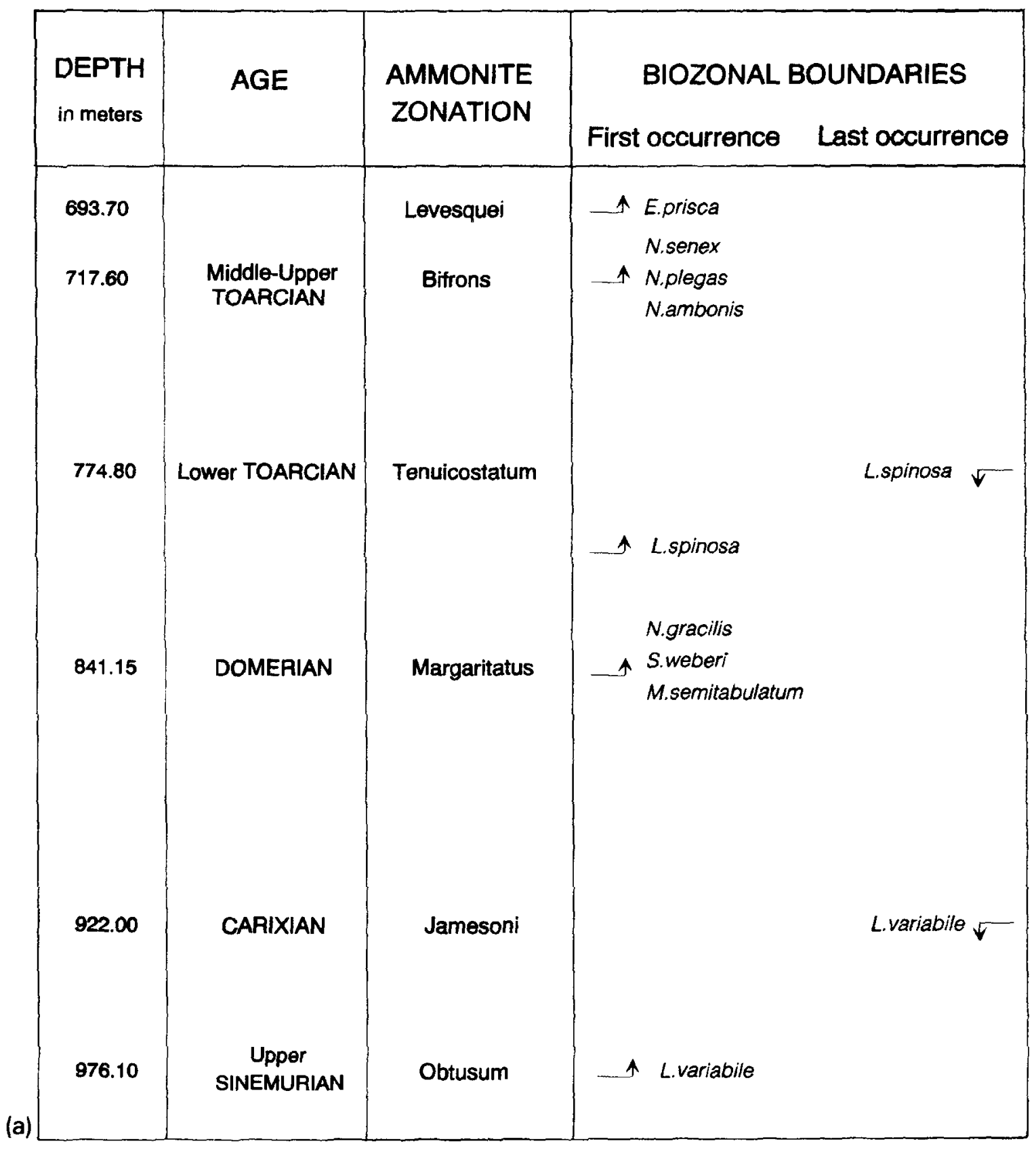

Fig. 4. Dinoflagellate cyst biozonation correlated with boreal ammonite zonation. (a) Lower Jurassic. 


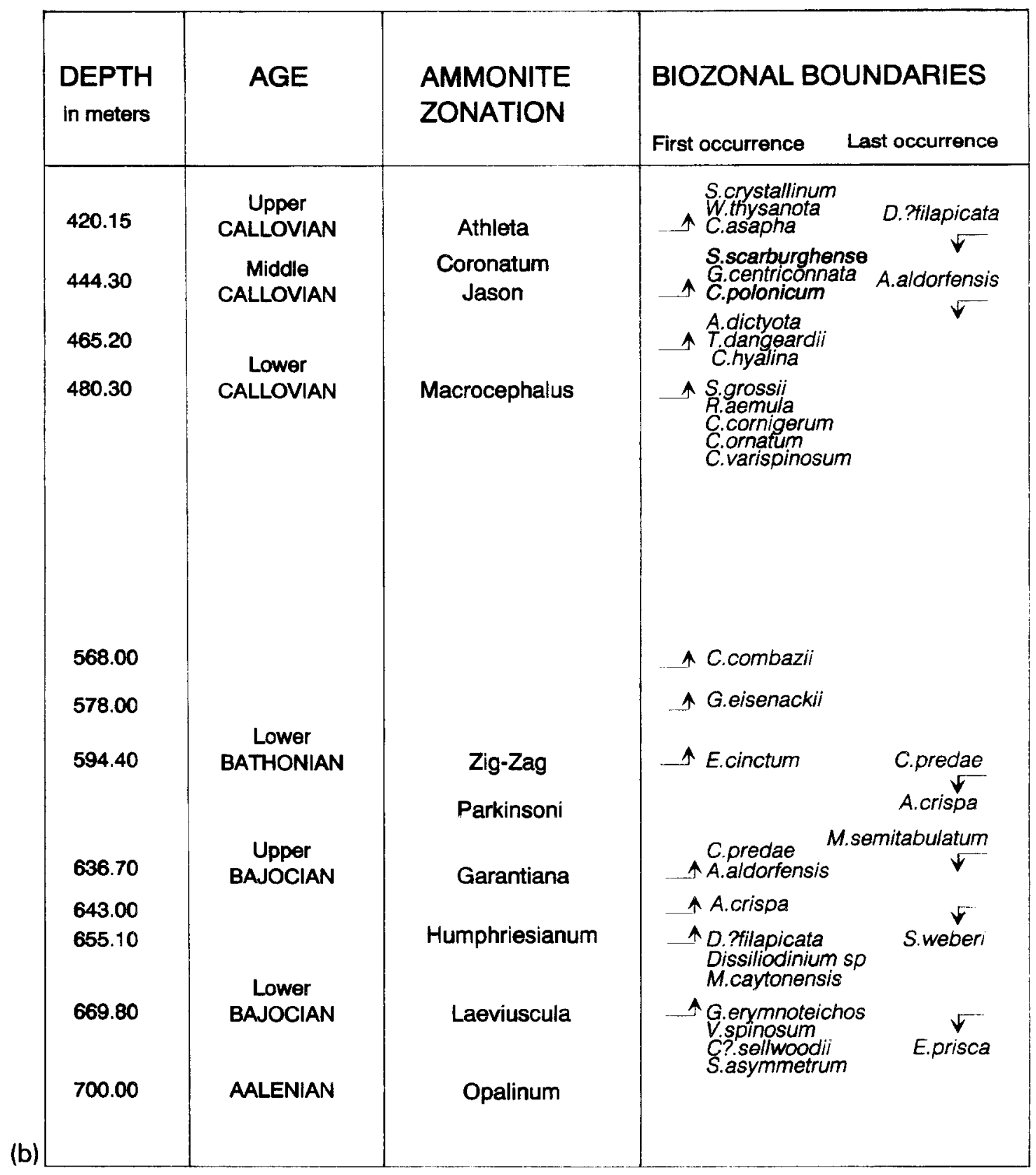

(b) Middle Jurassic. 


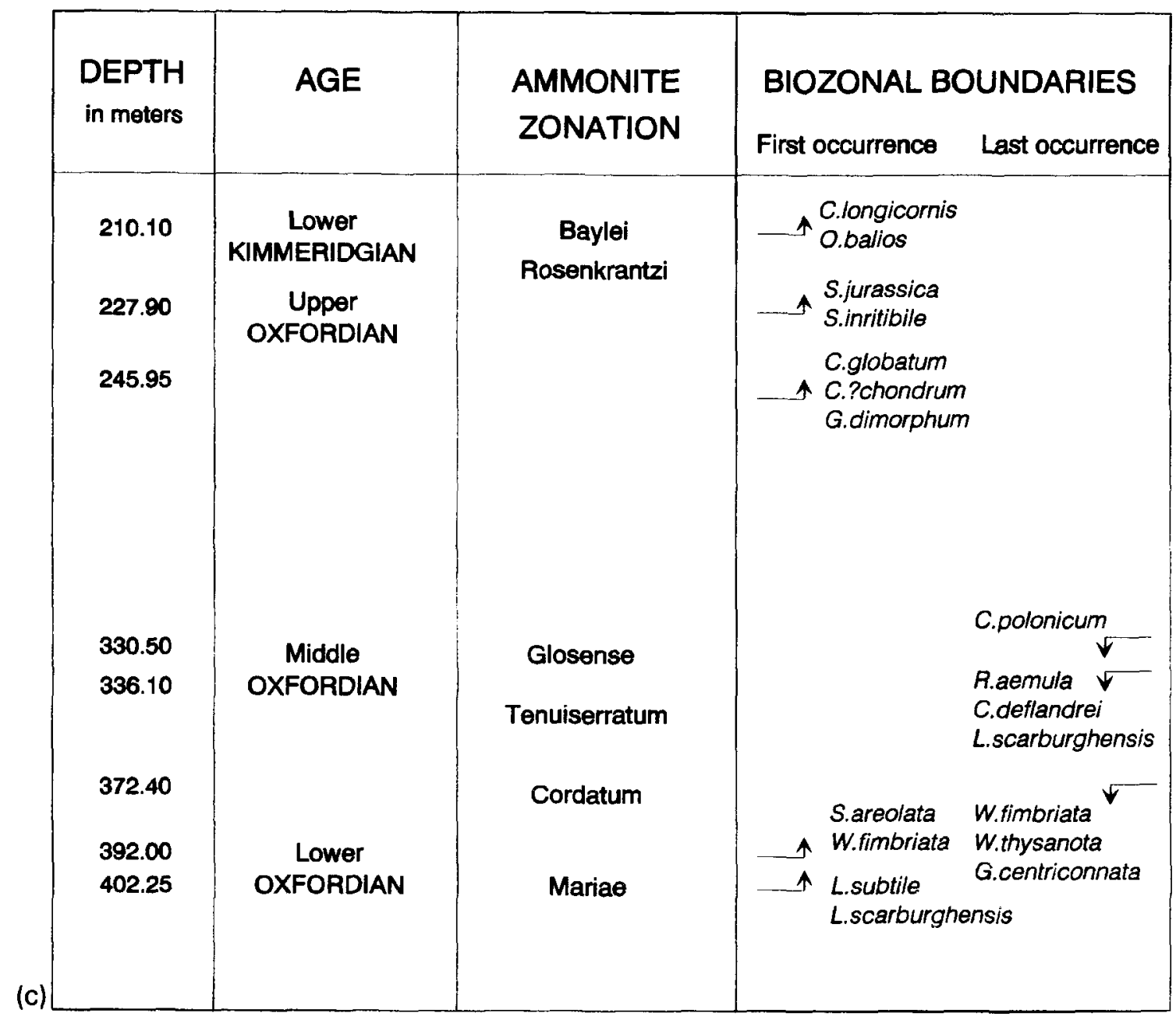

(c) Upper Jurassic.

\subsection{Lias}

In the basal beds, conifer pollen (Classopollis, disaccate) and pteridophyte spores dominate the association. The first dinoflagellate cysts appear only at $976.10 \mathrm{~m}$, in particular the marker species Liasidium variabile Drugg, 1978, which characterises the Obtusum zone of the upper Sinemurian; its disappearance at $922 \mathrm{~m}$ indicates the beginning of the Jamesoni zone.

The appearance of Mancodinium semitabulatum Morgenroth, 1970, Scriniocassis weberi Gocht, 1964, and Nannoceratopsis gracilis Alberti, 1961, indicates the beginning of the Margaritatus zone of the Domerian at $841.15 \mathrm{~m}$.

A marked change of palynofacies, with the appearance of abundant marine organic sapropelic material, Classopollis and inaperturate pollen, and algae (predominantly Tasmanaceae), associated with the disappearance of Luehndea spinosa Morgenroth, 1970, identifies the passage to the Tenuicostatum zone (lower Toarcian) at $774.80 \mathrm{~m}$. The same association, also found in England and other northwest European countries (Riding, 1987) suggests the widespread prevalence of anoxic conditions. 
A further change in the constitution of the organic material takes place at $717.60 \mathrm{~m}$, with increasing terrigenous input, in particular ligneous debris, conifer pollen and pteridophyte spores. Microplankton also reappears, in particular the genus Nannoceratopsis (N. plegas Drugg, 1978, $N$. senex van Helden, 1977, and $N$. ambonis Drugg, 1978), occuring in the Bifrons zone of the upper Toarcian. The appearance of Eyachia prisca Gocht, 1979 , at $693.70 \mathrm{~m}$ indicates the boundary between the upper Toarcian and basal Aalenian at the top of the Levesquei zone and the base of the Opalinum zone.

\subsection{Dogger}

At $669.80 \mathrm{~m}$, the beginning of the lower Bajocian (Laeviuscula zone) is identified by the appearance of Sentusidinium asymmetrum (Fenton et al., 1980) Lentin and Williams, 1981, Ctenidodinium? sellwoodii (Sarjeant, 1975) Stover and Evitt, 1978, and $5 \mathrm{~m}$ higher by Valveodinium spinosum Fenton et al., 1980, and Gongylodinium erymnoteichos Fenton et al., 1980. At $655.10 \mathrm{~m}$, the Humphriesanum zone is indicated by Meiourogonyaulax caytonensis (Sarjeant, 1959) Sarjeant, 1969, Dissiliodinium sp., and Dichadogonyaulax? filapicata (Gocht, 1970) Stover and Evitt, 1978, and at $643.00 \mathrm{~m}$ by the form Acanthaulax crispa (Wetzel, 1967) Woollam and Riding, 1983. The disappearance of Eyachia prisca confirms the passage to the Bajocian.

From $636.70 \mathrm{~m}$, the Garantiana zone is defined by the appearance of Aldorfia aldorfensis (Gocht, 1979) Stover and Evitt, 1978, and Carpathodinium predae (Béju, 1971) Drugg, 1978, and by the disappearance of Scriniocassis weberi, respectively, until the disappearance of Mancodinium semitabulatum.

The lower Bathonian is recognized:

(1) at $594.40 \mathrm{~m}$ ( Zig Zag zone) by the abundance of the genus Ctenidodinium, and the appearance of Ellipsodictyum cinctum Klement, 1960,

(2) at $578.00 \mathrm{~m}$ by the appearance of Gonyaulacysta eisenackii (Deflandre, 1938) Dodekova, 1967,

(3) at $568.00 \mathrm{~m}$ by the appearance of Ctenidodinium combazii Dupin, 1968, and also
(4) at $606.35 \mathrm{~m}$ by the disappearance of Acanthaulax crispa and Carpathodinium predae.

Between 568 and $480.30 \mathrm{~m}$ the hole passed through Bathonian gravelly oolites, unfavourable for microflora preservation.

Dinoflagellate cysts reappear at $480.30 \mathrm{~m}$, where they are characteristic of the Macrocephalus zone (lower Callovian), with Cleistosphaeridium varispinosum (Sarjeant, 1959) Woollam and Riding, 1983, Ctenidodinium ornatum (Eisenack, 1935) Deflandre, 1938, and, at $477.25 \mathrm{~m}$, with Ctenidodinium cornigerum (Valensi, 1953) Jan Du Chêne et al., 1985, Rigaudella aemula (Deflandre, 1938) Below, 1982, and Sirmiodinium grossii (Alberti, 1961) emend. Warren, 1973. At 465.20 $\mathrm{m}$, new forms appear, Chytroeisphaeridia hyalina (Raynaud, 1978) Lentin and Williams, 1981, Tubotuberella dangeardii (Sarjeant, 1968) Stover and Evitt, 1978, and Aldorfia dictyota (Cookson and Eisenack, 1960) Davey, 1982.

From $444.30 \mathrm{~m}$, the association becomes diversified with the addition of Compositosphaeridium polonicum (Gorka, 1965) Erkmen and Sarjeant, 1980, Gonyaulacysta centriconnata Riding, 1983, and Stephanelytron scarburghense (Sarjeant, 1961) emend. Stover et al., 1977, indicating the middle Callovian (Jason and Coronatum zones).

The Athleta zone of the upper Callovian is recognized at $420.15 \mathrm{~m}$ with the appearance of Clathroctenocystis asapha (Drugg, 1978) Stover and Helby, 1987, Wanaea thysanota Woollam, 1982, and Scriniodinium crystallinum (Deflandre, 1938) Klement, 1960, and the disappearance of Dichadogonyaulax? filapicata.

\subsection{Malm}

The passage from the upper Callovian to the lower Oxfordian (Mariae zone) is identified at $402.25 \mathrm{~m}$ with the appearance of the markers Liesbergia scarburghensis (Sarjeant, 1964) Berger, 1986, and Leptodinium subtile Klement, 1960. The Oxfordian is well defined at $392.00 \mathrm{~m}$ with Wanaea fimbriata Sarjeant, 1961, and at $385.00 \mathrm{~m}$ with Systematophora areolata Klement, 1960.

At $372.40 \mathrm{~m}$ the disappearance of Wanaea fimbriata, Wanaea thysanota Woollam, 1982, and Gonyaulacysta centriconnata Riding, 1983, defines 
the Cordatum zone of the lower Oxfordian. The middle Oxfordian (Tenuiserratum and Glosense zones) is characterized by the disappearance, at $336.10 \mathrm{~m}$, of Rigaudella aemula, Crussolia deflandrei Wolfard and Van Erve, 1981, and Liesbergia scarburghensis, until, at $330.50 \mathrm{~m}$, the disappearance of Compositosphaeridium polonicum. Dinoflagellate cysts become rare in the palynological thin sections of samples from the immediately overlying beds, and many species disappear.

The appearance, at $245.95 \mathrm{~m}$, of Glossodinium dimorphum Ioannides et al., 1977, Ctenidodinium? chondrum Drugg, 1978, and Cribroperidinium globatum (Gitmez and Sarjeant, 1972) Helenes, 1984, followed, at $227.90 \mathrm{~m}$, by Senoniasphaera jurassica (Gitmez and Sarjeant, 1972) Lentin and Williams,
1976, and Scriniodinium inritibile Riley in Fisher and Riley, 1980, indicates the upper Oxfordian.

Finally, the appearance, at $210.10 \mathrm{~m}$, of Occisucysta balios Gitmez, 1970, and the abundance of the genus Cribroperidinium suggest the passage to the basal Kimmeridgian (Baylei zone).

\section{Relations between abundances of dinoflagellate cysts and sea-level variations}

A fine-scale sedimentological study of the core from borehole A901 (Le Strat et al., 1991) enabled interpretation of the various facies in terms of palaeoenvironmental sequence curves and determination of the major evolutionary sequences; this

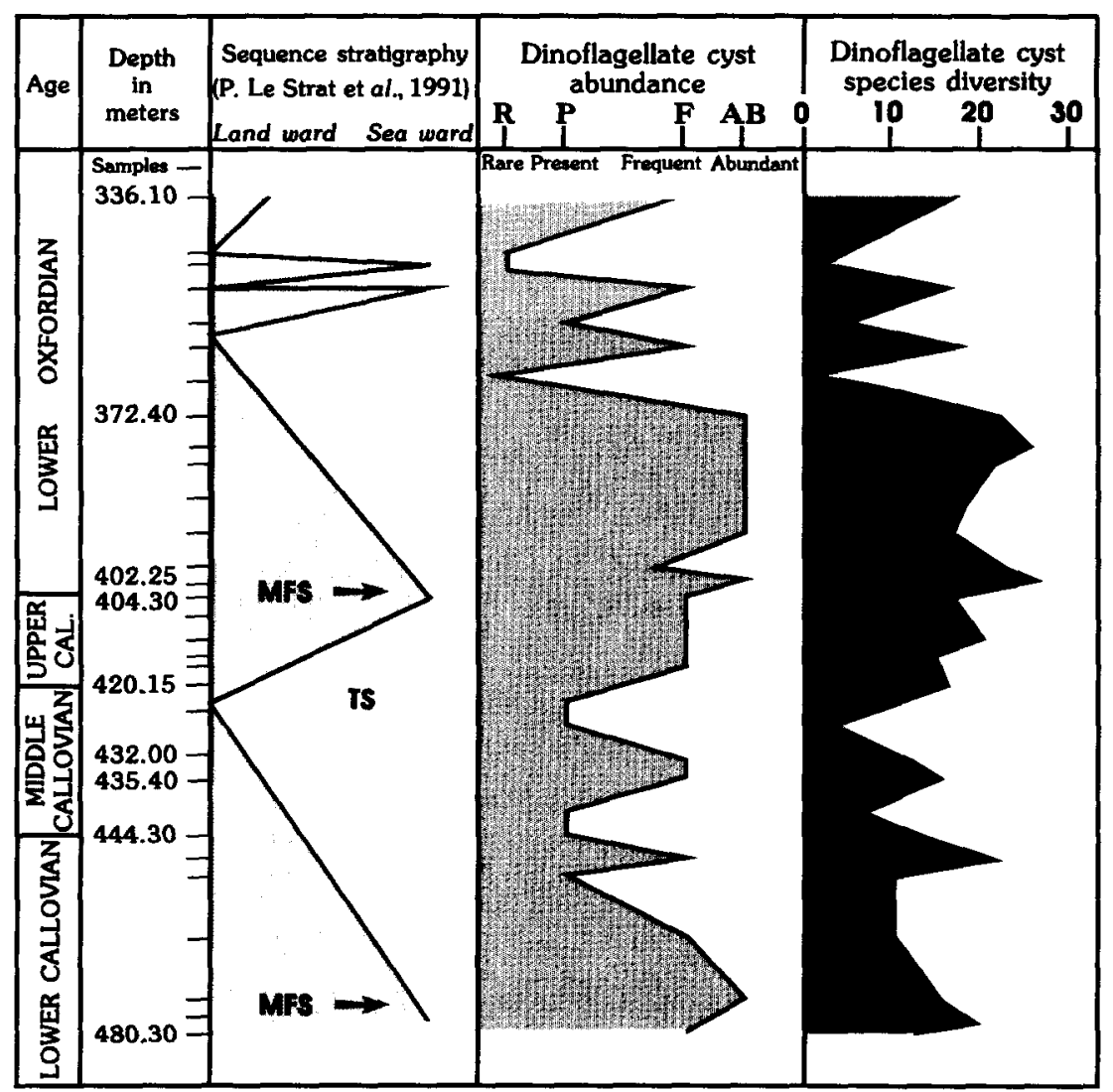

Fig. 5. Correlation between dinoflagellate cyst abundance and the Maximum Flooding Surfaces (MFS) from lower Callovian to lower Oxfordian. 
was complemented by an interpretation of seismic profiles. Biostratigraphic calibration was effected using ostracods, calcareous nannofossils and dinoflagellates (Le Strat et al., 1991; Trouiller et al., 1992). These combined data enabled an interpretation of the sequence stratigraphy and a definition of the main discontinuities and associated sedimentary bodies.

A semi-quantitative counting of dinoflagellate cysts was carried out in order to estimate the variations in abundance of microplankton and to determine their relations with sea-level changes. The lower Callovian-middle Oxfordian interval is particularly rich in dinoflagellates, and a positive correlation was found here (Fig. 5) between the semi-quantitative abundance, rare $(1-5 \%)$, present $(5-15 \%)$, frequent $(15-30 \%)$, abundant $(<30 \%)$, the species diversity $(0-27)$ of dinoflagellate cysts, and sea-level maxima at peaks of transgression, in particular at $404.30 \mathrm{~m}$, the lower Oxfordian Maximum Flooding Surface (MFS).

The number of species increased regularly from 5 to 20 as sea level rose from the Transgression Surface (TS) at $423.25 \mathrm{~m}$ to the beginning of the period of stable high sea level (Highstand System Tract-HST) at $404.30 \mathrm{~m}$. The HST continues up to $372.40 \mathrm{~m}$, and through this interval the number of species remains fairly high, at 18-27, after which the number decreases abruptly through the regressive sequence to $0-9$ species. Above $366.55 \mathrm{~m}$, the sea-level oscillations correspond to variations in microplankton abundance and the number of dinoflagellate cyst species. The most abundant and diversified dinoflagellate cyst associations are thus indeed found in the high sea-level deposits.

\section{Conclusions}

Dinoflagellate cysts are common to abundant in the Jurassic beds intersected in the cored borehole A901, drilled on the northeast edge of the Paris Basin, and enabled a biostratigraphical calibration. Most markers of the boreal domain have been found and located with respect to the ammonite zonation.

The continental microflora (pollen and spores) and the algae (Tasmanaceae, Botryococcus), com- monly associated with the microplankton in the lower Toarcian, indicate substantial variations in depositional environments during this period.

Semi-quantitative estimation of the abundance of microplankton and counting of the numbers of species enabled a correlation with sea-level variations, showing that highstand deposits contain the most abundant and diversified associations, in particular at the passage from the Callovian to the lower Oxfordian, where a transgressive maximum is associated with a large number of species.

\section{Acknowledgements}

The author would like to thank the National Agency for the Management of Radioactive Waste (ANDRA), particularly Mr A. Trouiller, for permission to publish the results of this study.

\section{References}

Alberti, G., 1961. Zur Kenntnis mesozoischer und alttertiärer Dinoflagellaten und Hystrichosphaerideen von Nord- und Mitteldeutschland sowie einigen anderen europäischen Gebieten. Palaeontographica A, 116: 1-58.

Béju, D., 1971. Jurassic microplankton from the Carpathian Foreland of Roumania. Ann. Inst. Geol. Publ. Hung., 54: 275-302.

Below, R., 1982. Rigaudella, ein neues Genus von Dinoflagellaten-Zysten. Neues Jahrb. Geol. Paläontol. Monatsh., 3: 137-150.

Berger, J.P., 1986. Dinoflagellates of the Callovian-Oxfordian boundary of the "Liesberg-Dorf" quarry (Berner Jura, Switzerland). Neues Jahrb. Geol. Paläontol. Abh., 172: 331-355.

Bjaerke, T., 1980. Mesozoic palynology of Svalbard IV, Toarcian dinoflagellates from Spitsbergen. Palynology, 4: $57-77$.

Conway, B.H., 1990. Paleozoic Mesozoic Palynology of Israël II Palynostratigraphy of the Jurassic Succession in the Subsurface of Israël. Geol. Surv. Isr. Bull., 82: 1-39.

Cookson, I.C. and Eisenack, A., 1960. Upper Mesozoic microplankton from Australia and New Guinea. Palaeontology, 2(1): 243-261.

Davey, R.J., 1982. Dinocyst stratigraphy of the latest Jurassic to early Cretaceous of the Haldager $N^{\circ} 1$ borehole, Denmark. Geol. Surv. Den. B, 6: 1-57.

Davies, E.H., 1985. The miospore and dinoflagellate cyst Oppel-zonation of the Lias of Portugal. Palynology, 9: $105-132$. 
De Vains, G., 1988. Etude palynologique préliminaire de l'Hettangien à l'Aalénien du Quercy (France). Bull. Cent. Rech. Explor.-Prod. Elf-Aquitaine, 12(1): 451-469.

Deflandre, G., 1938. Microplancton des mers jurassiques conservé dans les marnes de Villers-sur-Mer (Calvados). Etude liminaire et considérations générales. Trav. Stn. Zool. Wimereux, 13: 147-200.

Dodekova, L., 1967. Les dinoflagellés et acritarches de l'Oxfordien-Kimméridgien de la Bulgarie du Nord-Est. Annu. Univ. Sofia Fac. Géol. Géogr. 60(1), Géol. 1965-1966: 9-30.

Dodekova, L., 1975. New Upper Bathonian dinoflagellate cysts from north eastern Bulgaria. Bulg. Acad. Sci. Palaeontol. Stratigr. Lithol., 2: 17-34.

Drugg, W.S., 1978. Some Jurassic dinoflagellate cysts from England, France and Germany. Palaeontographica B, 168: 61-79.

Dupin, F., 1968. Deux nouvelles espèces de Dinoflagellés du Jurassique d'Aquitaine. Cah. Micropaléontol. Arch. Orig. Cent. Doc., Cent. Natl. Rech. Sci. 1, 450(8): 1-5.

Dybkjaer, K., 1988. Palynological zonation and stratigraphy of the jurassic section in the Gassum $\mathrm{N}^{\circ}$ 1-borehole Denmark. Dan. Geol. Unders. A, 21: 1-73.

Eisenack, A., 1935. Mikrofossilien aux Doggergeschieben Ostpreussens. Z. Geschiebeforsch., 11: 167-184.

Erkmen, U. and Sarjeant, W.A.S., 1980. Dinoflagellate cysts, acritarchs and tasminitids from the uppermost Callovian of England and Scotland: with a reconsideration of the "Xanthidium pilosum" problem. Géobios, 13: 45-99.

Feist-Burkhardt, S., 1990. Dinoflagellate cyst assemblages of the Hausen, boreholes (Aalenian to early Bajocian) Southwest Germany. Bull. Cent. Rech. Explor.-Prod. ElfAquitaine, 14(2): 611-633.

Fenton, J.P.G., 1981. Taxonomic revision of selected dinoflagellate cysts from the late Bajocian (Middle Jurassic) of northwest Germany. Rev. Palaeobot. Palynol., 31: 249-260.

Fenton, J.P.G., Neves, R., and Piel, K.M., 1980. Dinoflagellate cysts and acritarchs from Upper Bajocian to Middle Bathonian strata of Central and southern England. Palaeontology, 23: 151-170.

Fisher, M.J. and Riley, L.A., 1980. The stratigraphic distribution of dinoflagellate cysts at the boreal Jurassic-Cretaceous boundary. Proc. 4th Int. Palynol. Conf., Lucknow (1976-1977), 2, pp. 313-339.

Gitmez, G.U., 1970. Dinoflagellate cysts and acritarchs from the basal Kimmeridgian (Upper Jurassic) of England, Scotland and France. Bull. Br. Mus. Nat. Hist. Geol., 18: 231-331.

Gitmez, G.U. and Sarjeant, W.A.S., 1972. Dinoflagellate cysts and acritarchs from the Kimmeridgian (Upper Jurassic) of England, Scotland and France. Bull. Br. Mus. Nat. Hist. Geol., 21: 171-257.

Gocht, H., 1964. Planktonische Kleinformen aus dem Lias/ Dogger-Grenzbereich Nord und Süddeutschlands. Neues Jahrb. Geol. Paläontol. Abh., 119: 113-133.

Gocht, H., 1970. Dinoflagellaten-Zysten aux dem Bathonium des Erdölfeldes Aldorf (NW-Deutschland). Palaeontographica B, 129: 125-165.

Gocht, H., 1979. Eyachia prisca n.g. n. sp. (Dinoflagellata) aus dem Lias/Dogger-Grenzbereich. Neues Jahrb. Geol. Paläontol. Monatsh., 5: 305-319.

Gorka, H., 1965. Les microfossiles du Jurassique supérieur de Magnuszew (Pologne). Acta Palaeontol. Pol., 10: 291-327.

Haq, B.U., Hardenbol, J., Vail, P.R., 1988. Mesozoic and Cenozoic Chronostratigraphy and Cycles of Sea Level Change. Soc. Econ. Paleontol. Mineral. Spec. Publ., 42: $71-108$

Helenes, J., 1984. Morphological analysis of MesozoicCenozoic Cribroperidinium (Dinophyceae), and taxonomic implications. Palynology, 8: 107-137.

Ioannides, N.S., Stavrinos, G.N. and Downie, C., 1977. Kimmeridgian microplankton from Clavel's Hard, Dorset, England. Micropaleontology, 22: 443-478.

Ioannides, N.S., Colin, J-P. and Jan du Chêne, R., 1988. A preliminary investigation of Kimmeridgian Dinoflagellates and Ostracodes from Quercy, Southwest France. Bull. Cent. Rech. Explor.-Prod. Elf-Aquitaine, 12: 471-491.

Jan du Chêne, R., Fauconnier, D.C. and Fenton, J.P.G., 1985. Problèmes taxonomiques liés à la révision de l'espèce "Gonyaulax" cornigera Valensi, 1953, kyste fossile de dinoflagellé. Rev. Micropaléontol., 28(2): 109-124.

Klement, K.W., 1960. Dinoflagellaten und hystrichosphaerideen aus dem unteren und mittleren Malm Sudwestdeutschlands. Palaeontographica, A, 114: 1-104.

Le Strat, P., Andreieff, P., Bonijoly, D., Bonnemaison, M., Doumergue, J.L., Fauconnier, D., Lefavrais-Raymond, A., Marchand, D. and Trouiller, A., 1991. Stratigraphie séquentielle des séries jurassiques du sondage A901 AisneFrance. 3rd Int. Symp. Jurassic Stratigraphy, Poitiers, September 22-29, 1991 (abstr.).

Lentin, J.K. and Williams, G.L., 1976. A monograph of fossil peridinoid dinoflagellate cysts. Bedford Inst. Oceanogr. Rep. Ser., BI-R-75-16: i-vi, 1-127.

Lentin, J.K. and Williams, G.L., 1981. Fossil dinoflagellates: Index to Genera and Species, 1981 ed. Bedford Inst. Oceanogr. Rep. Ser., BI-R-81-12: 1-345.

Morgenroth, P., 1970. Dinoflagellate cysts form the Lias Delta of Lühnde/Germany. Neues Jahrb. Geol. Paläontol. Abh., 136: $345-59$.

Prauss, M., 1989. Dinozysten-stratigraphie und Palynofazies im Oberen Lias und Dogger von NW-Deutschland. Palaeontographica B, 241: 1-124.

Raynaud, J.F., 1978. Principaux dinoflagellés charactéristiques du Jurassique supérieur d'Europe du Nord. Palinologia Num. Extraord., 1: 387-405.

Riding, J.B., 1983. The palynology of the Aalenian (Middle Jurassic) sediments of Jackdaw Quarry, Gloucestershire, England. Mercian Geol., 9: 111-120.

Riding, J.B., 1984a. Dinoflagellate cyst range top biostratigraphy of the uppermost Triassic to lowermost Cretaceous of the northwest Europe. Palynology, 8: 195-210.

Riding, J.B., 1984b. A palynological investigation of Toarcian 
to early Aalenian strata from the Blea Wye area, Ravenscar, North Yorkshire. Proc. Yorkshire Geol. Soc., 45: 109-122.

Riding, J.B., 1984c. The palynology of the Tobar Ceann Siltstone Member, Staffin Shale Formation (Jurassic: Callovian/Oxfordian), Strathaird, southern Skye. Br. Geol. Surv. Rep., 16: 1-5.

Riding, J.B., 1987. Dinoflagellate cyst stratigraphy of the Nettleton Bottom Borehole (Jurassic: Hettangian to Kimmeridgian), Lincolnshire, England. Proc. Yorkshire Geol. Soc., 46: 231-266.

Riding, J.B. and Thomas, J.E., 1992. Dinoflagellate cysts of the Jurassic System. In: A.J. Powell (Editor), A Stratigraphic Index of Dinoflagellate Cysts. BMS Ser. Chapman and Hall, London.

Sarjeant, W.A.S., 1959. Microplankton from the Cornbrash of Yorshire. Geol. Mag., 96: 329-346.

Sarjeant, W.A.S., 1961. Microplankton form the Kell-aways Rock and Oxford Clay of Yorkshire. Palaeontology, 4: 90-118.

Sarjeant, W.A.S., 1964. New name and diagnosis for an Upper Jurassic species of Gonyaulacysta (Dinophyceae). Palaeontology, 7: 472-473.

Sarjeant, W.A.S., 1968. Microplankton from the Upper Callovian and Lower Oxfordian of Normandy. Rev. Micropaleontol., 10: 221-242.

Sarjeant, W.A.S., 1969. Taxonomic changes. In: R.J. Davey, C. Downie, W.A.S. Sarjeant and G.L. Williams, Appendix to "Studies on Mesozoic and Cainozoic dinoflagellate cysts". Bull. Br. Mus. Nat. Hist. Geol., Appendix Suppl., 3: 7-15.

Sarjeant, W.A.S., 1975. Jurassic dinoflagellate cysts with epitractal archeopyles. A reconsideration. Grana, 14: 49-56.

Smelror, M. and Aarhus, N., 1989. Emendation of the dinoflagellate cyst genus Crussolia Wolfard and Van Erve 1981, and description of $D$. dalei $n$. sp. from the Callovian of Svalbard. Neues Jahrb. Geol. Paläontol. Monatsh., 1: $37-46$.

Smelror, M. and Leereveld, H., 1989. Dinoflagellate and acritarch assemblages form the late Bathonian to early Oxfordian of Montagne Crussol, Rhône Valley, southern France. Palynology, 13: 121-141.

Stover, L.E. and Evitt, W.R., 1978. Analyses of pre-Pleistocene organic-walled dinoflagellates. Stanford Univ. Publ. Geol. Sci., 15: 1-300.

Stover, L.E. and Helby, R., 1987. Some Early Cretaceous dinoflagellates from the Houtman-1 well, Western Australia. In: P.A. Jell (Editor), Studies in Australian Mesozoic Palynology. Assoc. Aust. Palaeontol Mem., 4: 261-295.

Stover, L.E., Sarjeant, W.A.S. and Drugg, W.S., 1977. The Jurassic dinoflagellate genus Stephanelytron: emendation and discussion. Micropaleontology, 23: 330-338.

Thusu, B., van der Eem, J.G.L.A., El-Mehdawi, A. and Bu-Argoub, F., 1988. Jurassic-Early Cretaceous palynostratigraphy in northeast Libya. In: A. El-Arnauti, B. Owens and B. Thusu (Editors), Subsurface Palynostratigraphy of Northeast Lybia. Garyounis Univ. Publ., Benghazi, pp. 171-213.

Trouiller, A., Jacquin-Ponsot, C., Jan Du Chềne, R. Fauconnier, D., Le Strat, P. and André-Jehan, R., 1992. Lias sequence stratigraphy Northern Paris Basin-Borehole A901. In: Sequence Stratigraphy of European Basins, May 18-20, 1992. Abstr. Vol.

Vail, P.R., Colin J.P., Jan du Chêne, R., Kuchly, J., Mediavilla, F. and Trifilieff, V., 1987. La stratigraphie séquentielle et son application aux corrélations chronostratigraphiques dans le Jurassique du Bassin de Paris. Bull. Soc. Géol. Fr. (8), 3(7): $1301-1321$.

Valensi, L., 1953. Microfossiles des silex du Jurassique moyẹn. Remarques pétrographiques. Mém. Soc. Géol. Fr., 68, $100 \mathrm{pp}$.

Van Helden, B.G.T., 1977. Correlation of microplankton assemblages with ammonite faunas from the Jurassic Wilkie Point Formation, Prince Patrick Island, District of Franklin. Geol. Surv. Can. Pap., 77-1 B: 163-171.

Warren, J.S., 1973. Form and variation of the dinoflagellate Sirmiodinium grossi Alberti, from the Upper Jurassic and Lower Cretaceous of California. J. Paleontol., 47: 101-114.

Wetzel, W, 1967. Mikroorganismen aux jurassischen und kretazischen Saurier-Gewöllen. Z. Dtsch. Geol. Ges., 116: $867-874$.

Wolfard, A. and Van Erve, A.W., 1981. Crussolia deflandrei nov. gen. et nov. sp., a dinoflagellate cyst from the Jurassic (Callovian-Lower Oxfordian) of Montagne Crussol, Rhône Valley, France. Rev. Palaeobot. Palynol., 34: 321-329.

Woollam, R., 1982. Observations on the Jurassic dinocyst genera Energlynia and Wanaea. J. Micropalaeontol., 1: 45-52.

Woollam, R. and Riding, J.B., 1983. Dinoflagellate cyst zonation of the English Jurassic. Rep. Inst. Geol. Sci., $83(2): 1-42$. 